\title{
ОБ ИСТОРИЧЕСКИХ СУДЬБАХ \\ И МЕЖДУНАРОДНО-ПРАВОВОМ СТАТУСЕ \\ АДЖАРИИ - ОДНОЙ ИЗ АВТОНОМНЫХ ЧАСТЕЙ ГРУЗИИ
}

(Рецензия на книгу А.Х. Абашидзе "АДЖАРИЯ. История, дипломатия, международное право", Москва, АО "РАУ. Университет", 1998 г., 326 с.):

Разрушение Советского Союза, появление на его обломках огромного числа новых национальных больших и малых государств, их борьба за свой суверенитет, связанные с этим военные действия и конфликты, стремление обосновать право на независимость и опровергнуть такое же право своего национального противника все это породило за последние годы поток национально-политической литературы.

Ориентироваться в ней непросто. Ибо одна из главных особенностей этой апологетическо-полемической литературы на национально-исторические темы - ее пестрота как в политическом, так и в научном отношении, в тематическом угле зрения (эткическом, демографическом, экономическом, историческом и т.д.) и не в последнюю очередь в уровне приводимой аргументации. Есть работы явно пустые, поверхностные, есть книги, обеспеченные источниками, есть чистая публицистика, эмоции, а в целом - невозможность для стороннего читателя объективно разобраться в степени достоверности всех этих изданий, где национальная или политическая предвзятость превалирует, бьет через край.

Вот почему и чтение, и тем более рецензирование такой литературы крайне затруднены. Они предполагают знание комплекса тех национально-исторических вопросов, которые подымают и излагают авторы, и которым далеко не всегда располагают рецензенты.

Как справедливо отмечалось на прошедшем в ноябре 1998 года круглом столе историков СНГ, все советские историки крайне плохо знают историю населявших СССР народов, владеют в лучшем случае знанием лишь какой-то узкой сферы или тематики. И этот факт препятствует не только объективной оценке наводнившей книжный рынок национально-политической литературы, но и вообще делает ее "вешью в себе", информация о ней не становится объектом широкого общественного внимания, а остается уделом мелких враждуюших политических кланов и группировок, хотя основной смысл публикации таких работ и состоит в том, чтобы привлечь к той или иной национальной проблеме более широкий круг сторонников, завоевать, просветить, информировать обшественность. 
Но в силу сложившихся обстоятельств (отсутствие специалистов, предвзятость рецензентов, малые тиражи, сумбурное, эмоциональное или тяжелое псевдонаучное изложение) мы все еще крайне слабо и плохо ориентируемся в качестве, направлениях и объективном значении указанной национально-политической литературы, не всегда даже можем распознать фальсификацию, отличить апологетику от научно-добросовестного произведения.

Обо всем этом приходится особо напоминать, приступая к рецензированию очередной книги, посвяшенной характеристике национальной территории, ибо первое, что должен сказать рецензент читателю, - это какое место занимает данная книга в обрисованной выше литературе, к какой категории она принадлежит и что представляет собой ее автор. Книга "Аджария" принадлежит, к счастью, к числу серьезных работ. Она носит отчасти исторический и отчасти международно-правовой характер и систематически обрисовывает исторические судьбы Аджарии в хронологическом порядке, давая о ней представление как о части национальной грузинской территории. Книга насыщена историческими документами: заявлениями разных правителей Грузии и ее княжеств, мирными договорами, архивными документами внешнеполитического характера.

Автор, по профессии юрист-международник, предпочитает давать целиком или в выдержках весь документ, а не ссылаться на него в сносках, как это обычно принято у историков. И хотя это прерывает хронологически последовательное повествование, но не мешает ему и оправдано тем, что автор стремится дать читателям широкого круга, не знаюшим многих исторических вопросов, возможность лично заглянуть в тот или иной подлинный текст.

В целом работа написана спокойно, убедительно, создает довольно ясную картину исторической судьбы Аджарии в истории Грузии. И это объяснимо - автор - доктор юридических наук, советник не только Федерального Собрания России, но и Председателя Верховного Совета Аджарской автономной республики по международноправовьм вопросам, профессионал высокого класса, хорошо знающий излагаемый предмет. Правильнее было бы сказать, что в данном случае мы имеем изложение вопроса из первых рук. И это обеспечивает достоверность материала и общее научное качество книги.

Я подчеркиваю это потому, что, будучи автором справочника “Внешняя политика Руси, России и СССР" и работая над очередной третьей книгой Выпуска II, посвяшенной войнам и мирным договорам России со странами Азии, мог убедиться, что автор не пропустил ни одного значительного исторического события в отношениях России с народами Закавказья, упомянул главнейшие исторические документы русско-турецких отношений, касающиеся Аджарии, и даже, может быть, слишком подробно воспроизвел мало известный 
в советской исторической литературе период с марта по ноябрь 1918 года, почти дословно приведя все мнения всех значительных политических деятелей Закавказья по вопросам их отношения $к$ Турции, Германии, Англии, Брестскому миру и к России, так что это дает в конце концов хотя и пеструю, но ясную картину растерянности и неспособности местных закавказских деятелей разбираться в большой политике, решать верно внешнеполитические проблемы. Несомненно, что этот чисто исторический материал бросает некоторый проясняющий луч и на ту ситуацию, которая сложилась в Закавказье в 90-е годы. Многое просто аналогично.

Крайне интересным, свежим, ранее не известным широкому кругу историков материалом служит раздел книги о британской политике в отношении Закавказья и Грузии в XIX веке. Автор пользовался материалами британских архивов, добытыми для него недавно корреспондентом грузинского информационного агентства в Лондоне В.Н. Катамидзе.

Из них мы узнаем о разведывательной деятельности Англии в Закавказье и в Грузии в 30-50-е годы XIX в., еще накануне Крымской войны, об английских планах противодействия России в этом регионе и даже о намерении вытеснить Россию из Закавказья, и о наметках создать там британский протекторат.

Эти сведения по-новому объясняют не как случайный эпизод, а как логическое продолжение всю британскую политику на Кавказе в течение всего XIX века, а также в период гражданской войны 19181922 годов и... разумеется в нынешнее время.

Но, указывая особо на некоторые “изюминки" данной книги, нельзя, конечно, упускать из вида главного - то, что она дает слитную, цельную картину истории Аджарии и ее современного международно-правового и государственно-правового положения. Если резюмировать то главное, что сообщает книга, то, опуская весь документальный, вставной, иллюстрирующий отдельные эпизоды материал, ее основное содержание выглядит следующим образом:

Государственная история Аджарии начинается с IV-III веков до н.э., когда она впервые упоминается как отдельное княжество, одна из шести административных единиц Грузии. С самого начала Аджария как страна делилась на две географические части - Приморскую и Горную. Приморская - от Батуми до Кобулети была самой важной, стратегически притягательной и экономически развитой. Поэтому она часто подвергалась иностранным нашествиям и захватам. Вначале она входила в Колхидское царство (Лазику), затем в Понтийское, потом в Иберийское государство, а в V веке н.э. стала ареной греко-персидского соперничества и в VIII веке - ареной византийско-грузинских войн и арабского завоевания, ликвидировавшего вообще грузинское государство. 
Когда грузины вновь создали Тао-Кларджетское государство в XI-XII веках, то Османская империя турок-сельджуков, направившая в XV веке свою агрессию на запад, в Европу, и уничтожившая Византию, дошедшая через покоренные Балканы до Австрии и Чехии, в XVI веке начинает воевать на востоке с Нраном и делит с ним в 1555 году Закавказье, в том числе и Грузию, по Сурамскому перевалу. Аджария попадает по этому разделу в турецкую зону и тем самьм оказывается изолированной на 300 лет от основной Грузии, находившейся в иранской зоне. Это и определило особые исторические пути развития Аджарии, превращение ее населения из христианского в мусульманское.

Хотя аджарцы сохранили свой родной грузинский язык, национальную одежду и бытовые обычаи, но в религиозном отношении они стали отличаться от православных грузин. Аджарцы - это грузинские мусульмане. И это создавало для них не только особое религиозное положение, но и вело $\mathrm{x}$ их иному правовому положению, а населяемую ими страну Аджарию ставило в особое международноправовое положение, чем все остальные грузинские территории.

Если в отношении грузинских территорий, населенных православными, русские цари, начиная с Ивана IV Грозного, могли выступать с претензиями к исламским государствам - Турции и Ирану, если они могли предпринимать внешнеполитические шаги по зашите, протекции, военной помощи единоверным грузинским государствам - Кахетии, Карталинии, Имеретии, то в отношении Аджарии никаких мер по ее защите от турецкого угнетения не могло быть предпринято. Ибо Аджария была внутренней турецкой территорией, даже административно не выделенной, а целиком слитой с турецкими вилайетами, и с международно-правовых позиций любая защита Аджарии выглядела бы поэтому необоснованной и расценивалась бы как грубое вмешательство в чисто турецкие внутренние дела.

Только после серии русско-турецких войн XVIII века - начала XIX века, когда Россия одержала ряд побед, заввершившихся территориальными присоединениями Крьма, Бессарабии, Грузии (Имеретии, Мингрелии, Гурии), и русско-турецкая граница подошла $\mathrm{k}$ 30-м годам XIX в. непосредственно к Аджарии, Россия смогла поставить в повестку дня своей восточной внешней политики и освобождение из-под турецкого ига единокровного с остальными грузинами народа Аджарии.

Но и эта задача в тот момент требовала времени, тщательной подготовки и выбора благоприятной международной обстановки, которая определялась соотношением сил великих держав в Европе. Тем самым решение аджарского вопроса было напрямую связано с большой внешней политикой, а не было лишь местным, кавказским, мелким пограничным мероприятием. И в этом заключалось своеоб- 
разие положения Аджарии, этим определялось ее место во внешней и военной политике России на Черном море.

Таким образом, судьба Аджарии с $30-\mathrm{x}$ годов XIX в. зависела от того, насколько будет сильна Россия, насколько ее голос будет весом в мировой политике, в ансамбле великих держав, и, конечно, насколько прочны будут ее позиции в Закавказье.

Во время Крымской войны 1853-1856 годов позиции России сильно ослабли. Но в начале 70-х годов ее положение на Черном море укрепилось, а в результате русско-турецкой войны 1877 1878 годов укрепилось настолько, что можно было поставить вопрос в мирном договоре о присоединении Аджарии. Поскольку усилению России в Закавказье активно противилась Англия, то особо выгодные условия мира в Сан-Стефано для России были ослаблены затем Берлинским договором 1878 года и Константинопольским 1879 года. Но тем не менее Аджария с Батумом все же вошли на этот раз в состав России и были воссоединены с остальной Грузией после 300-летнего перерыва.

Русские власти не просто присоединили аджарские территории, оторвав их от Турции, но и собрали их все вместе и выделили в отдельный Батумский округ, сформировав его из трех административно разрозненных турецких территорий. Аджария была не только освобождена, но и восстановлена в своих этнических и географических границах как страна, получила центр, “столицу” Батум, ставший в начале XX века (1903 г.) благодаря русским капиталовложениям и строительству третьим по значению городом в Закавказье после Тбилиси и Баку! Ясно, что без России подобного стремительного развития не произошло бы.

В первую мировую войну противником России на Кавказском фронте вновь оказалась Турция. Ее действия не были успешны, и Аджария осталась вне военных действий. Но в силу общей международной обстановки после первой мировой войны Аджария оказалась потерянной. Дело в том, что Кавказский фронт после Октябрьской революции не мог контролироваться Советской властью. Он оказался в руках местной власти - закавказских мелкобуржуазных националистов, которые не имели своих военных сил, не признавали Советской России и остались один на один со своими внешнеполитическими проблемами перед лицом Турции, Германии и Англии, разрывавших Кавказ на части.

Поэтому Грузия отдала Аджарию Турции, не сумев в то же время предотвратить и турецкой оккупации своей основной территории.

Только восстановление советской власти в Закавказье, создание ЗСФСР и советско-турецкий договор, заключенный от имени РСФСР с Ататюрком, привели к возвращению Аджарии в состав советской Грузии, а тем самым и в СССР. 
Аджария была провозглашена автономной республикой в составе Грузии, и за годы советской власти (1921-1991 гг.), т.е. в течение 70 лет, испьтала самый большой экономический, культурный и национальный подъем за все время своей истории. Как подчеркивает автор, это был период самого мирного, нарастающего, поступательного развития за всю историю Аджарии. Немудрено, что когда СССР был развален и по этому поводу в разных частях бывшего Союза наступило ликование некоторых крайних националистических сил, принявшихся обострять отношения с соседями и "брать себе как можно больше суверенитета", в Аджарии совершенно не разделяли подобных настроений. Наоборот, местные аджарские руководители, в полном согласии со свонм народом, постарались сделать все возможное, чтобы сохранить, не дать разрушить хозяйственно-культурный уровень, достигнутый в советское время, и не допустить в пределах границ республики никаких националистических эксцессов и нарушения ее автономного статуса.

Аджария осталась автономной республикой - единственной на территории бывшего СССР. У нее сохраняется относительно стабильное экономическое положение, в то время ках на остальной территории Грузии царит политический, хозяйственный и социальный хаос, а также созданы два очага военных конфликтов: грузино-абхазская война против независимости Абхазии и вооруженное подавление югоосетинской областной автономии.

Автор приводит убедительные факты, показывающие, что попытки грузинских центральных властей всеми силами уничтожить самостоятельность и автономию национальных меньшинств Грузии, ликвидировать прошедшую историческую проверку на прочность государственность малых народов - абхазов, осетин, месхитинцев, а также ликвидировать автономию Аджарии, - могут иметь своим логическим и политическим результатом ослабление Грузии как государства и ее развал, распад, поскольку такая политика, такие антинациональные идеи не могут никогда получить поддержку народов.

Автор определяет подобную политику как авантюристическую, гибельную для сушествования самого грузинского государства и призывает грузинское руководство, пока еще не поздно, отказаться от поддержки этого порочного политического курса.

Что же касается положения Аджарии, то А.X. Абашидзе, как юрист-международник, подчеркивает, что его республика помимо общих демократических прав, существующих в цивилизованном обществе, а именно права на свою исторически закрепленную и выстраданную государственность и права нации на самоопределение и национальную автономию, обладает и особьм формальноправовым документом международного ранга на неприкосновен- 
ность своих границ и своего государственного существования, а именно - гарантируюшим Аджарии эти права Карсским мирным договором, который совсем недавно, в 1992 году, был подтвержден в грузино-турецком договоре о дружбе и добрососедстве. Таким образом, автономный статус Аджарии имеет не только национально-исторические и политические обоснования, но и обеспечен международно-правовыми документами.

Если Грузия в такой ситуации пойдет все же на ликвидацию автономии Аджарии, то она будет иметь дело с нарушением международных договоров и тем самым лишит себя доверия со стороны мирового сообшества, не говоря уже о том, что грузинское давление на Аджарию может быть формально опротестовано и перед $\mathrm{OOH}$, и перед Международным Судом.

Таким образом, книга А.Х. Абашидзе сообщает нам полную историческую и современную информацию, касающуюся положения Аджарии в Грузии и аджаро-грузинских отношений. В современной литературе, посвященной национальному вопросу в разных частях бывшего СССР, эта книга - заметное явление.

В.В. Похлебкин, кандидат исторических наук

Рецензия поступила в редакцию в декабре 1998 г.

\section{САМЫЕ ВЫСОКИЕ ДОХОДЫ - В СНГ}

Журнал американских деловых кругов «Business Week» привел любопытные подсчеты. Оказывается, оффшорные фонды, в которых накапливаются средства для инвестиций, уходящие по международным контрактам в проекты на рынках стран СНГ, занимают самые верхние строчки в рейтингах аналогичных фондов во всех других государствах мира.

В частности, в первую десятку самых доходных входят фонды СНГ, Китая и Восточной Европы, а на первых трех местах - все из СНГ: первый - «Russian property» (272\% годового дохода за период с осени 1996 г. до осени 1997 г.), второй - «Brunswick Russian Growth» $(214,36 \%)$, третий — «Regent White Tiger» $(141,03 \%)$.

Самымн худшими, с убыточными показателями, ведущими эти аккумулирующие деньги организации к банкротству, стали последний в списке оффшорный фонд «Fidelity Thailand» из Таиланда $(-61,24 \%)$, предпоследний - «JF Japan OTС» из Японии $(-51,28 \%)$ и третий от конца - «JF Philippine» из Филиппин $(-51,28)$.

(Соб. инф.) 